\title{
Effect of seed enhancement treatment on field performance of chickpea (Cicer arietinum $\mathrm{L}$.)
}

\author{
Mukesh Kumar ${ }^{1 *}$, Amarendra Kumar², Rakesh Kumar ${ }^{3}$, Shiv Kumar Yadav', Rajbir \\ Yadav $^{4}$ and Jitendra Kumar ${ }^{5}$ \\ ${ }^{1}$ Division of Seed Science and Technology, Indian Agricultural Research Institute, New Delhi - 110012, INDIA \\ ${ }^{2}$ Department of Plant Pathology, Bihar Agricultural University, Sabour, Bhagalpur - 813210 (Bihar), INDIA \\ ${ }^{3}$ Division of Agricultural Physics, Indian Agricultural Research Institute, New Delhi - 110012, INDIA \\ ${ }^{4}$ Division of Genetics, Indian Agricultural Research Institute, New Delhi - 110012, INDIA \\ ${ }^{5}$ Division of Agricultural Chemical, Indian Agricultural Research Institute, New Delhi - 110012, INDIA \\ "Corresponding author. E-mail: mukesh.iari@gmail.com
}

Received: January 14, 2015; Revised received: June 21, 2015; Accepted: July 10, 2015

\begin{abstract}
Chickpea (Cicer arietinum L.) is an important winter season pulse crop in India grown in drought prone semi-arid and tropical regions. The aim of present investigation was to find out the effect of seed enhancement treatment on field performance of chickpea. Seeds of Chickpea Desi cultivar Pusa 256, Pusa 2028, and Kabuli cultivar Pusa1053, Pusa1108, each of fresh and 4 yrs old lots were taken for seed enhancement treatments like osmo-priming, halo-priming, fungicidal, botanical and polymer coating alone and in combination with thiram and neem oil. It was observed that seed treatment with thiram alone or in combination with polymer (PVP or PEM) significantly enhances germination and field emergence. Old seed lots of particularly Pusa 256 gives better result. The speed of emergence was invariably high in fresh seed lot (9.43) than old seed lots (4.84). However, in old seed lots, only halo-priming and polymer (PVP) in combination with thiram improved the speed of emergence significantly. Thus seeds treatment with thiram or in combination with hydrophilic polymers could be used for enhancing the performance of chickpea.
\end{abstract}

Keywords: Chickpea, Field emergence, Speed of emergence, Seed priming

\section{INTRODUCTION}

Chickpea (Cicer arietinum L.) is a rainfed, low inputs, winter leguminous crop used in various foods in several developing countries, particularly in India as a source of dietary protein. It is a rich source of highly digestible dietary protein (17-21 per cent), carbohydrate (61.5 per cent) and fat (4.5 per cent). It is also rich in calcium, iron, niacin, vitamin $\mathrm{B}$ and vitamin $\mathrm{C}$. The major chickpea producing countries in Asia are India (65\%), Pakistan (7.5\%) and Turkey (6.5\%). India grows chickpea on 8.56 million ha are producing 7.65 million tonnes (FAO, 2011) and having productivity $858 \mathrm{~kg} / \mathrm{ha}$. There are two type of chickpea viz desi and kabuli, grown in the world recognized visually by seed coat colour and seed size. The desi types is characterized by small seed size and thick seed coat with pale to dark brown in colour, where as kabuli type is large seed size cream in colour with thick seed coat. The productivity level of pulses is not sufficient due to unavailability of quality seeds of improved varieties, several biotic and abiotic stresses and poor crop management practices. The planting value of seed is one of the key factors for proper plant establishment and performance, particularly under moisture stress conditions. Use of quality seed alone has been reported to improve productivity in chickpea from 15-20 percent (Dahiya et al., 1997). The most cost effective method available for better stand establishment is to sow the seed with high germination which shows quick early growth. The major constraints of good establishment are due to low quality seed in addition to lack of soil moisture (Gurumu and Naylor, 1991). These conditions result in poor emergence that may subsequently cause sparse plant stands (Saxena et al., 1997). One way of improving productivity of chickpea in drought prone area is seed enhancement treatment. Pre-sowing seed treatment including chemical, polymer coating, botanical and priming treatments are known to improve seed performance. Priming applied to commercial seed lots is widely used by seed technologists to enhance seed vigour in terms of germination potential and increased stress tolerance. The seed priming process simply involves soaking the seed overnight (for about $8 \mathrm{hrs}$ ), surface drying them and sowing within the same day (Musa et al., 2001) to hasten germination, enhances crop establishment and promotes seedling vigor (Harris et al., 1999). Treating the seed before sowing with fungicide prevent fungal invasion particularly in young seedlings. Seed treatment with captan, thiram, mancozeb and 
carbendazim shows significant improvement in field emergence and yield (Anuja and Aneja, 2000). The effects of seed coating with different polymeric formulations in general deteriorate at slower pace as manifest in high germination percentage (Kumar et al., 2007). The effect of seed treatment with powdered neem and neem oil formulations was to suppress nematode population growth and increased grain yield significantly in chickpea (Vijaylakshmi and Majumdar, 1999). Quick and synchronized germination is desirable to set crop successfully in order to compete with weed species and better seed performance. This was achieved by priming, which involves controlled hydration that restricts germination but permit pre germinative physiological and biochemical changes to occur (Bradford et al., 1990; Khan, 1992). Osmo-priming has shown to promote in rate and uniformity of germination in several crops. Seed treatment with PEG-6000 was found to increase germination per cent and seedling growth in Tomato, Capsicum, Cauliflower, Brinjal and Onion (Pandita and Nagarajan 2000, Cantliffe 2003, Pandita et al. 2007, Singh, et al. 2014; Usha and Dadlani, 2014). Field performance of seeds with low and average planting value was enhanced by seed enhancement treatment. Keeping this fact in view the present investigation was undertaken to find most appropriate seed enhancement treatment for better field performance in chickpea.

\section{MATERIALS AND METHODS}

Seeds and treatment materials: The seed material for this study constituted eight seed lots i.e. two each of desi (Pusa 256 and Pusa 2028) and kabuli (Pusa1053 and Pusa1108) from both freshly harvested and four year old seed lots. The fresh seed lots were available from Division of Seed Science and Technology, Indian Agricultural Research Institute, New Delhi and four years old seed lots were collected from Pulse Laboratories, Indian Agricultural Research Institute, New Delhi. Seeds selected for experiment were bold and free from any damage. The polymer polyvinyl pyrrolidane (PVP) and polyethyl methyl acrylate (PEM) were obtained from Division of Agriculture Chemical, Indian Agricultural Research Institute, New Delhi

Seed treatments: The treatment $\mathrm{T}_{2}$ i.e. Osmo-priming was done by polyethylene glycol (PEG8000) solution containing $25 \mathrm{~g}$ PEG dissolved in $100 \mathrm{ml}$ water. The eight replicate of 50 seeds placed in $\mathrm{PEG}$ saturated two layers of filter paper in petri plate for $48 \mathrm{hrs}$ at $20^{\circ} \mathrm{C}$. Similarly, treatment $\mathrm{T}_{3}$ i.e. halo-priming was done by taking 2 percent solution of $\mathrm{KNO}_{3}$ instead of PEG. Primed seeds were rehydrated for next $24 \mathrm{hrs}$ at room temperature before sowing. Fungicidal treatment $\mathrm{T}_{4}$ and botanical seed treatment $\mathrm{T}_{5}$ were done with thiram (a) 2g per kg of seed and neem oil @ 4ml per kg of seed respectively. The details of seed treatments are given in table 1. For preparation of seed coating formulation $4.0 \mathrm{~g}$ of each polyvinyl pyrrolidone (PVP) and polyethyl methyl acrylate (PEM) and mixture of $0.10 \mathrm{~g}$ sodium lauryl sulphate (act as binder) and $0.15 \mathrm{~g}$ Sodium lingosulfonate (act as surfactant) were added to water and a wet grind was prepared individually for both the polymers. These polymer alone @ 4.0ml per $\mathrm{kg}$ and in combination with thiram and neem oil were applied to seed by seed coating machine.

Germination (\%): Eight replicate of 50 seeds of each variety and each treatments were tested for germination studies as per ISTA method (Anonymous, 2004). In this method, seed were placed between two layer of wet germination paper which was then rolled and wrapped in wax sheet and placed in germinator in an upright position under $20 \pm 1^{\circ} \mathrm{C}$ and $95 \% \mathrm{RH}$ for 8 days. On the day of final count i.e. $8^{\text {th }}$ day, it were evaluated for normal seedling, abnormal seedling, dead and hard seed. All the damaged, decayed and deformed seedling which were not able to produce normal seedling were counted and considered as abnormal seedling. Germination percentage was calculated on the basis of normal seedling.

Field emergence and speed of emergence (SOE): Field emergence was estimated by sowing 100 seeds in 4 replications in the field. Observations were recorded on alternate day till $30^{\text {th }}$ day of sowing. The emergence was expressed as percentage of seedling emergence.

Speed of emergence calculated by following formula $\mathrm{SOE}=\sum(\mathrm{N} / \mathrm{T})$

Where $\mathrm{N}$ is number of seeds emerging at time $\mathrm{T}$ and $\mathrm{T}$ is days from sowing.

Statistical analysis: The data from laboratory experiment were collected by adopting complete randomized design (CRD), while data collected from field experiment were through Random block design (RBD) as prescribed by Panse and Sukhatme (1985). The data was analysed by using the software SPSS10.0.

\section{RESULTS AND DISCUSSION}

Germination (\%): The effect of seed enhancement treatments on germination in both fresh as well as old seed lots as shown in table 2. In the fresh seed lots, varieties differed significantly for germination and maximum germination was observed in desi types. When viewed over treatment, Pusa 256 had significantly $(\mathrm{P}=0.05)$ higher germination (95.73\%) than Pusa 2028. The treatments also differed significantly in their effect on germination (\%). Among different seed treatments, thiram, neem oil, polymer (PVP and PEM) in combination with thiram had significantly increased germination over control (Table 2).

Among old seed lots, desi types were significantly higher germination than kabuli Type. Pusa 256 had significantly higher germination $(84.73 \%)$ than other three varieties. The seed treatment with thiram followed by osmo-priming had increased germination significantly over the control. 
Table 1. Details of seed enhancement treatments on chickpea.

\begin{tabular}{clcl}
\hline S.N. & Treatments & Code & \multicolumn{1}{c}{ Dosage } \\
\hline 1 & Control & $\mathrm{T}_{1}$ & \multicolumn{1}{c}{-------- } \\
2 & Osmo-priming & $\mathrm{T}_{2}$ & $25 \%$ Solution (w/v) \\
3 & Halo-priming & $\mathrm{T}_{3}$ & $2 \%$ Solution (w/v) \\
4 & Thiram & $\mathrm{T}_{4}$ & $2.5 \mathrm{~g} / \mathrm{Kg}$ \\
5 & Neem oil & $\mathrm{T}_{5}$ & $4 \mathrm{ml} / \mathrm{Kg}$ \\
6 & Polymer(PVP) & $\mathrm{T}_{6}$ & $4 \mathrm{ml} / \mathrm{Kg}$ \\
7 & Polymer(PVP) + Thiram & $\mathrm{T}_{7}$ & $4 \mathrm{ml} / \mathrm{Kg}+2.5 \mathrm{~g} / \mathrm{Kg}$ \\
8 & Polymer(PVP) + Neem oil & $\mathrm{T}_{8}$ & $4 \mathrm{ml} / \mathrm{Kg}+4 \mathrm{ml} / \mathrm{Kg}$ \\
9 & Polymer(PEM) & $\mathrm{T}_{9}$ & $4 \mathrm{ml} / \mathrm{Kg}$ \\
10 & Polymer(PEM) + Thiram & $\mathrm{T}_{10}$ & $4 \mathrm{ml} / \mathrm{Kg}+2.5 \mathrm{~g} / \mathrm{Kg}$ \\
11 & Polymer(PEM) + Neem oil & $\mathrm{T}_{11}$ & $4 \mathrm{ml} / \mathrm{Kg}+4 \mathrm{ml} / \mathrm{Kg}$ \\
\hline
\end{tabular}

Table 2. Effect of seed enhancement treatments on germination (\%) of fresh and old seed lots of chickpea.

\begin{tabular}{|c|c|c|c|c|c|c|c|c|c|c|c|c|c|c|}
\hline & $\begin{array}{l}\text { Treat } \\
\text { ment } \\
\text { s }\end{array}$ & & T1 & $\mathbf{T 2}$ & T3 & T4 & T5 & T6 & $\mathbf{T 7}$ & T8 & T9 & T10 & T11 & Mean \\
\hline Lot & Type & Variety & & & & & & & & & & & & \\
\hline \multirow[t]{5}{*}{ Fresh } & Desi & Pusa 256 & 95 & 95 & 97 & 96 & 96 & 97 & 95 & 95 & 95 & 97 & 95 & 95.73 \\
\hline & & $\begin{array}{l}\text { Pusa202 } \\
8\end{array}$ & 93 & 95 & 92 & 96 & 95 & 93 & 96 & 93 & 93 & 96 & 95 & 94.27 \\
\hline & Kabuli & $\begin{array}{l}\text { Pusa } \\
1053\end{array}$ & 92 & 93 & 91 & 96 & 93 & 92 & 95 & 93 & 94 & 95 & 93 & 93.36 \\
\hline & & $\begin{array}{l}\text { Pusa110 } \\
8\end{array}$ & 91 & 93 & 92 & 95 & 95 & 93 & 96 & 95 & 92 & 95 & 94 & 93.73 \\
\hline & & Mean & 92.75 & 94.00 & 93.00 & 95.75 & 94.75 & 93.75 & 95.5 & 94.00 & 93.50 & 95.75 & 94.25 & 94.27 \\
\hline \multicolumn{15}{|c|}{ 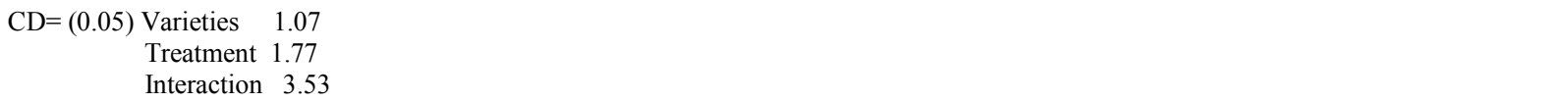 } \\
\hline \multirow[t]{5}{*}{ Old } & Desi & Pusa 256 & 81 & 85 & 87 & 87 & 84 & 83 & 86 & 85 & 85 & 87 & 82 & 84.73 \\
\hline & & $\begin{array}{l}\text { Pusa202 } \\
8\end{array}$ & 81 & 79 & 75 & 84 & 81 & 82 & 83 & 83 & 85 & 81 & 89 & 82.09 \\
\hline & Kabuli & $\begin{array}{l}\text { Pusa } \\
1053\end{array}$ & 65 & 67 & 67 & 65 & 62 & 60 & 57 & 56 & 58 & 59 & 56 & 61.09 \\
\hline & & $\begin{array}{l}\text { Pusa110 } \\
8\end{array}$ & 58 & 61 & 60 & 63 & 62 & 58 & 61 & 57 & 58 & 58 & 60 & 59.64 \\
\hline & \multicolumn{2}{|c|}{$\mathrm{CD}=(0.05)$ Varieties $\quad 0.71$} & 71.25 & 73.00 & 72.25 & 74.75 & 72.25 & 70.75 & 71.75 & 70.25 & 71.50 & 71.25 & 71.75 & 71.89 \\
\hline $\mathrm{CD}=(0$. & $\begin{array}{l}\text { 5) Variet } \\
\text { Treatn } \\
\text { Intera }\end{array}$ & $\begin{array}{ll} & 0.71 \\
\text { ent } & 1.168 \\
\text { tion } & 2.34\end{array}$ & & & & & & & & & & & & \\
\hline
\end{tabular}

Field emergence: Analysis of variance for field emergence data generated for fresh and old seed lots revealed significant difference for varieties and treatments (Table 3). The interaction effect between varieties and treatments were significant only in old seed lots. In fresh seed lots, field emergence (92.45\%) was quite high in both desi and kabuli types. However emergence was significantly high in desi type $(93.41 \%)$ than in kabuli type $(91.50 \%)$. In old seed lots, in contrast, desi varieties has quite high field emergence i.e. more than $78 \%$ but in kabuli type, there is significant reduction in field emergence in old seed lots with value $15.64 \%$ in Pusa1053 and $21-18 \%$ in Pusa 1108. The field emergence data for fresh seed lots revealed that all treatment has higher value than control. However, treatment with thiram and polymer (PVP or PEM) in combination with thiram and neemoil improve the emergence significantly.

Speed of Emergence: Speed of emergence data is revealed that interaction between varieties and treatments were significant only in old seed lots (Table 4). It is invariably high in fresh seed lots (9.43). However, the difference in old and fresh seed lots in speed of emergence was more pronounced in kabuli type varieties Pusa 1053 and Pusa 1108. In kabuli types speed of emergence was drastically reduced on aging. Treatment response of fresh seed lots was more toward thiram, neemoil and polymer (PVP) in combination with thiram. However, in old seed lots, only halopriming and polymer in combination with thiram improve the speed of emergence significantly over control. The correlation matrix indicated that field emergence was significantly correlated with germination percentage $\left(\mathrm{r}=0.48^{*}\right)$ but there was no significant correlation observed with speed of emergence.

The above results showed the effect of seed enhancement treatments to improve the seed quality of chickpea. All eleven seed enhancement treatment showed enhancing impact on field performance of chickpea cultivar. Seed enhancement treatments influenced the 
Table 3. Effect of enhancement treatment on field emergence (\%) of fresh and old seed lots of chickpea.

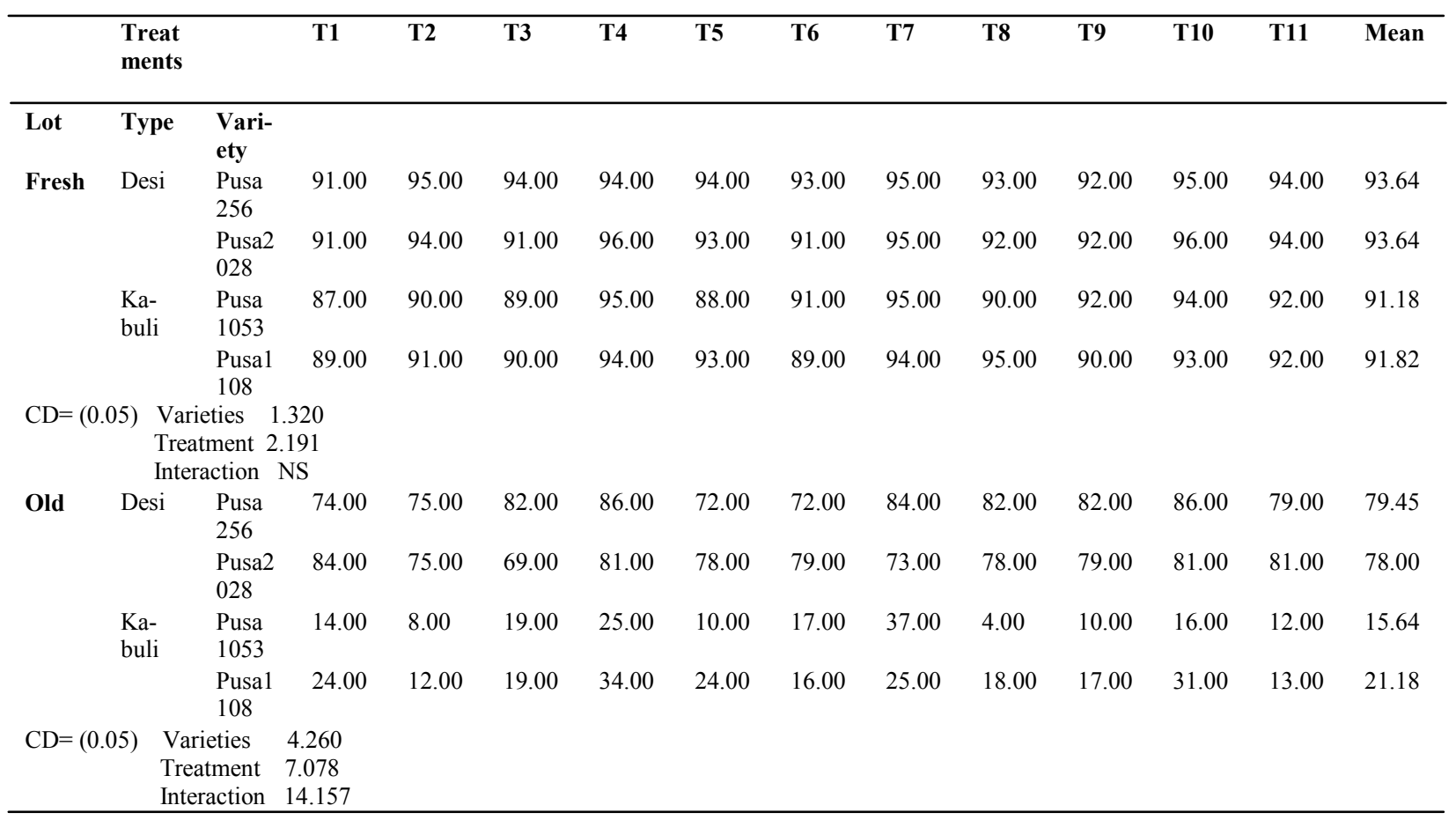

Table 4. Effect of enhancement treatment on speed of emergence of fresh and old seed lots of chickpea.

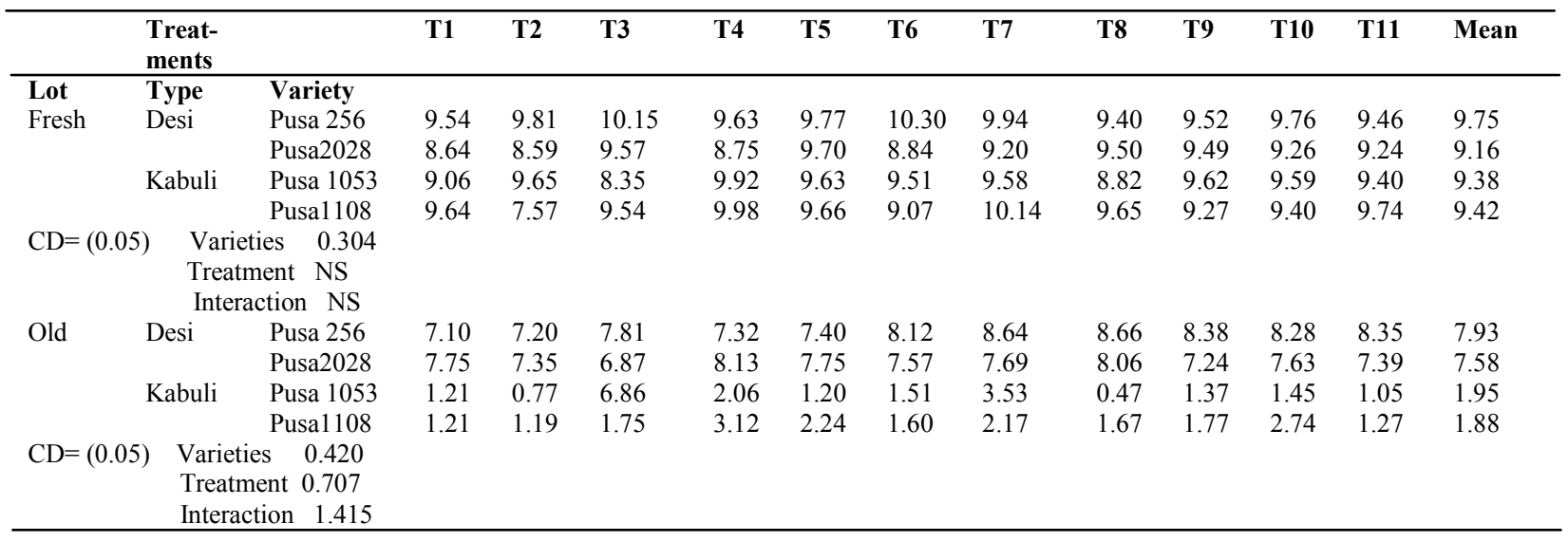

physiological and biochemical process in the seeds, and thereby contribute to greater vigor and improved crop stand. The highest improvement in germination and seedling vigor and emergence due to hydro-priming were observed in poor vigor seed lot of chickpea (Ghassemi-Golezani et al., 2012). Usha and Dadlani (2014) showed the effect of pre-sowing treatments i.e. polymer coating polykote with fungicides thiram and Royalflo were most effective in enhancing the germination, seedling growth and field emergence in all the cultivars of soybean. The osmo-priming $(-1.0 \mathrm{MPa}$ for 2 days $)$ and solid matrix priming $\left(20^{\circ} \mathrm{C}\right.$ for $\left.24 \mathrm{hrs}\right)$ can be successfully used to improve germination and field emergence of onion seeds (Singh et al., 2014). The priming response was attributed mainly to rapid seedling establishment, with higher plant stand and earlier crop maturity allowing escape from end-of -season stresses in on-farm priming study in chickpea. Priming also reduced the incidence of stem and root diseases, and increased nodulation by native rhizobia (Musa et al., 2001). The effect of osmotic priming on onion (Allium cepa L.) seedling emergence was evaluated in the field and in a controlled environment and showed that Seedlings from primed onion seed emerged $7 \%$ to $18 \%$ sooner than seedlings from unprimed seed in all field and laboratory experiments (Murry and Swensen, 1992). Such enhanced performance has also been reported in other crops (Musa et al., 2001; Murry and Swensen, 1992; Pandey et al., 2005; Usha and Dadlani, 2014; Singh et al., 2014). Field emergence was varieties specific with desi types having more emergences largely because of high germination and more seedling length. On ageing not only reduced emergence but also slow in speed of 
emergence. Hence seed enhancement treatment plays important role in better plant establishment.

\section{Conclusion}

The poor crop establishment is one of the major bottlenecks for chickpea production. Seed enhancement treatments have maximized the probability of obtaining a good stand of healthy and vigorous plants that would be appropriate to improve the livelihood of resource-poor farmers. The present study revealed that varieties were diverse for various vigour parameters. In general, desi varieties showed higher germination and field emergence in both fresh as well as old seed lots in comparison to kabuli types. Field emergence and speed of emergence were significantly very low in old seed lots of Kabuli types. The seed treatment with thiram alone or in combination with polymer (PVP or PEM) had significant effect in enhancing germination and field emergence. It was also observed that old seed lots were more responsive to treatments than fresh seed lots and effect of priming treatments were specific to varieties. Thus, it was concluded that seeds treated either with thiram or in combination with hydrophilic polymers could be used for enhancing the planting value in chickpea.

\section{REFERENCES}

Anuja, G. and Aneja, K.R.(2000). Field efficiency of seed dressing chemical on seedling emergence, seed yield and seed weight in soybean. Seed Research, 28(1):54-58.

Bradford, K.J., Steiner, J.J. and Trawatha, S.E.(1990). Seed priming influence on germination and emergence of Pepper seed lot. Crop Science, 28:1001-1005.

Cantliffe, D.J. (2003). Seed enhancement ISHS Acta Horticulturae 607: IX International Symposium on Timing of Field Production in Vegetable Crops, Sao Paulo, 13 May 2003, 34(1).

Dahiya, O.S., Tomer, R.P.S. and Ashwani (1997). Evaluation on the viability and vigour parameters with respect to field emergence in chickpea (Cicer arietinum L.). Seed Research, 25(1):19-24.

FAO (2011). Production Year Book, Food and Agriculture Organizations of United Nations (FAO), Rome Italy.

Ghassemi-Golezani, K., Hosseinzadeh-Mahootchy, A., Zehtab-Salmasi, S. and Tourchi, M. (2012). Improving field performance of aged chickpea seeds by hydro-priming under water stress. International Journal of Plant, Animal and Environ. Sci., 2(2):168-176.

Gurumu, M. and Naylor, R.E.L. (1991). Effects of low water potential on germination of two sorghum varieties. Seed
Sci. and Tech., 19:373-383.

Harris, D., Joshi, A., Khan, P.A., Gothkar, P. and Sodhi, P. S. (1999). On farm seed priming in semiarid agriculture: development and evaluation in maize, rice and chickpea in India using Participatory methods. Experimental Agric., 35: 15-29.

Khan, A.A. (1992). Pre-plant physiological seed conditioning. Horticultural Reviews, 14:131-181.

Kumar, J., Nisar, K., Kumar, A.M.B., Walia, S., Shakil, N.A., Prasad, R., Balraj, S. and Parmar, B.S.(2007). Development of polymeric seed coats for seed quality enhancement of soybean (Glycine max). Indian Journal of Agric. Sci., 77(11): 738-743.

Murry, G.A. and Swensen, J.B. (1992). Emergence of spring and summer planted onion following osmotic priming. Horticulture Sci., 27(5):409-411.

Musa, A.M., Johansen, C. and Kumar, J. (2001). Short duration chickpea to replace fallow after amen rice: The role of on farm seed priming in the high barren track of Bangladesh. International Chickpea and Pigeonpea Newsletter, 6:20-22.

Pandey, S., Kumar, J. and Parmer, B.S. (2005). Polymer seed coating on soybean and maize for seed quality enhancement and better emergence. Annals Agric. Res. New Series, 26(4):509-513.

Pandita V.K., Anand A. and Nagarajan S., (2007). Enhancement of seed germination in hot pepper following pre-sowing treatments. Seed Science and Technology, 35: 282-290.

Pandita, V.K. and Nagarajan, S. (2000). Osmopriming of fresh seed and its effect on accelerated ageing in Indian tomato (Lycopersicon esculentum) varieties. Indian Journal of Agricultural Sciences 70(7): 479-480.

Panse, V.G. and Sukhatme, P.V. (1985). Statistical methods for agricultural workers, 1.C.A.R. Pub., New Delhi.

Saxena N.P., Saxena M.C., Johansen, C. (1997). Chickpea ideotypes for low-and-high input conditions. In A.N. Asthana and M Ali (Eds.), "Recent Advances in Pulses Research," pp.217-231. Indian Society of Pulses Research and Development, Indian Institute of Pulse Research (IIPR), Kanpur, India.

Singh, P.K., Pandita, V.K. , Tomar, B.S. and Seth, R. (2014). Germination and field emergence in osmotic and solid matrix priming in onion (Allium cepa). Indian Journal of Agric. Sci., 84 (12): 1561-1564.

Usha, T.N. and Dadlani, M. (2014). Enhancement of planting value and storage performance of different cultivars with various germinabality of soybean (Glycine max) seed by pre treatment. Legume Res., 37 (5): 467-472.

Vijaylakshmi and Majumdar, V. (1999). Effect of seed treatment of chickpea with crude neem product and neem based pesticide on nematode multiplication in soil and grain yield. International Journal of Nematology, 9 (1):76-79. 